\title{
Neapolitan Language
}

National Cancer Institute

\section{Source}

National Cancer Institute. Neapolitan Language. NCI Thesaurus. Code C154043.

A Romance language of the Italo-Dalmatian group spoken across much of southern Italy. 